\title{
Slaves, Government and Politics in Ibadan, 1835 - 1893
}

\author{
Salami, B. Olawale \\ (Ph.D)Department of History and Diplomatic Studies Faculty of Arts Olabisi Onabanjo University, P.M.B 2002, \\ Ago-Iwoye, Ogun State, Nigeria
}

\begin{abstract}
One of the greatest experiments in State building in pre-colonial Yorubaland, particularly after the great Oyo Empire was bedevilled with constitutional crisis, was depicted by the military state of Ibadan. In the period under discourse, governance in Ibadan was highly decentralised but purposeful. Both the freeborn and slaves were drafted into state building and statecraft. This paper captures the importance of soldier-slaves in the development of Ibadan between 1835 and 1893. Of particular interest in this article are the important roles such soldier-slaves played in toll collection, security of lives and property, administration of justice and as permanent representatives of Ibadan in conquered regions.
\end{abstract}

Keywords - Government, Ibadan, Nigeria, Politics, Slaves,

\section{Introduction}

Ibadan is a town in the south-western part of Nigeria. Its traditional inhabitants are the Yoruba people. The town is reputed to be the largest in West Africa and has very rich history. The pre-colonial state of Ibadan was one of the states that grew out of the crisis that bedevilled Yorubaland. The two others were Ijaiye and Abeokuta. Out of the three states, Ibadan's appetite for militarism was unequalled by other states in Yorubaland. The state systematically grew from a war camp to a strong military state with a brilliant record of successes in various wars. The many successes of the Ibadan warriors in their military campaigns to establish a balance of power in the Yoruba country, manifested in the acquisition of large expanse of territories, especially in the eastern part of Yorubaland. Ibadan also became the defender of Yoruba country from external invaders, particularly the Hausa-Fulani Jihadists, who tried to infiltrate the region from the north. Having established firm control over the conquered territories, the effective control of the satellite regions fell on the Ajele, the resident political representatives of Ibadan. Many of the Ajele were slaves. At home, slaves were also involved in toll collection, market administration and administration of justice.

The soldier-slaves were mainly used as toll collectors and as escorts to traders. They were part of the law enforcement agents and many times, the responsibility fell on them to execute punishments on behalf of the state. Some of them were made political residents of the conquered towns. These slaves were in most cases treated particularly by the Ologun, more as political collaborators, than as slaves and were not always viewed with contempt. From time to time, the Ologun made it a point of duty to identify themselves with the soldierslaves in all ramifications. The soldier-slaves were allowed to wear their caps in the presence of their chiefs, a practice forbidden to non-soldiers even if they were freemen [1].

\section{Slaves as gate-keepers and toll collectors}

In the nineteenth century Ibadan, and like any other Yoruba state of the period, the Ologun were always in charge of the town gates. The town gates were massive and the chiefs in most cases had their compounds very close to them. Each of such gates were placed under the watchful eyes of a chief not only for the collection of tolls, but for security purposes [2]. However, the political and economic functions of the chiefs were not personally performed by the chiefs. Each chief had his representatives in form of his trusted soldier-slaves who collected the tolls. The soldier-slaves collected the tolls both in cash and kind. The traders paid tolls varying from 40-200 cowries depending on the volume of their merchandise. Those that engaged in farming activities outside the town wall also paid tolls in kind on their return in the evening. A head or two heads of corn, a handful of beans, a tuber or two tubers of yam and a few other farm products [3], were some of the articles used for payment of tolls. It should be noted that the Onibode (gate-keepers), were rarely, if at all, chosen from the freeborn soldiers. The practice was wide-spread in the Yoruba country that it became an adage ' $a$ ki fi omoluwabi je Onibode' meaning that 'a freeborn is never made a gate-keeper" [5].

It must however, be emphasised that making gate management and toll collection the exclusive preserve of the soldier-slaves, evidently, did not stem from any contempt felt for them, but from a desire to provide some recompense for their services. The gate-keepers however, made good of their jobs. They effectively managed all the sixteen gates [6], possessed by Ibadan. The number of gates Ibadan had was unprecedented in the history of Yorubaland, hence, people used to say of Ibadan that 'all towns have four corners, Ibadan alone have sixteen' (igun merin ni gbogbo ilu nni, merindinlogun ni ti 'Badan) [7]. Meanwhile, 
the gate-keepers gave the larger share of the tolls collected to their masters and whatever surplus there may be in a brisk season, they appropriated to themselves.

\section{Slaves as escorts to traders and visitors}

In the area of security of lives and property, the soldier-slaves discharged their duties with dispatch and with all seriousness. They escorted traders and travellers when the roads were generally unsafe due to the nauseating activities of robbers, kidnappers and slave-raiders. For instance, in 1851, when David Hinderer was leaving Ibadan for Abeokuta at the end of his first missionary work, he was officially provided with an escort of 30 soldier-slaves who were made up of 10 from the Bale (Oyesile Olugbode, 1851-1865), 10 from the Agbakin and 10 from the Balogun (Ibikunle, 1851-1864). In addition to the official party, two young Ologun voluntarily mounted their horses' back and led about 50 soldier-slaves to accompany Hinderer as far as the other side of Ona River. Hinderer, reciprocating this good gesture and assistance, gave the escorts about 4 dollars worth of cowries for a country feast on their return [8]. The traders not only paid tolls, they also paid for the escorts they were provided with by the soldier slaves. Although, some may argue that the extra money paid to these soldierslaves might have constituted hindrances to trade which could have resulted in the withdrawal of some traders, who might have seen it as extra burden, the argument is not convincing because there was no record of reduction of trade as well as withdrawal of traders. And in fact, if there was any reduction in the volume of trade, probably, it was due to the unsafe condition of the trade routes. It has however, been established that the traders never saw such payments as hindrances and that it never affected their profit margin adversely. The traders were always turning out in large numbers to form caravans. According to Oroge, [1] they probably must have realised that they were paying the Ologun and their soldier-slaves for the protection offered without which trade would have been virtually impossible.

\section{Slaves in the Administration of Justice}

Slaves were also part of market administrators. Ojaba, (Bashorun's Market) the largest of the markets had the largest number of such officials who were appointed by the state. In the smaller markets, it was the chiefs in charge of such markets who appointed their soldier-slaves as the officials. The market officials saw to the maintenance of law and order in the markets, tried minor cases at the market places while they referred the more serious ones to their masters or the central authority. They were also to collect market dues. The officials were easily identified by the cutlasses, swords or guns which they carried while on duty. In Ojaba and a few other markets, they had permanent places which they used as their posts. Some of them also operated outside Ibadan markets where Ibadan traders attended. In the areas where Ibadan had no political control, like in the Egba and Ijebu markets, Ibadan Market officials had no much power. But in those areas where Ibadan had exercised direct political control like in the northern and eastern Yorubaland, they were very powerful. There, they had power over both Ibadan and foreign traders. Moreover, slaves took part in public works like constructing and repairing of markets and trade routes. In fact, it was only in compounds where large slaves were not available, that the freeborn were used for such public works. The building of town walls was also undertaken mainly by the slaves [11].

What was more, slaves also featured prominently in the administration of justice. Although the justice that had to be administered in the pre-colonial days was not in accordance with any written code of laws, with a body of beliefs, customs and codes of manners, people and property were still to be protected against anti-social actions. Therefore, people were expected to be aware of what was good and bad. Adultery, stealing and other vices were not allowed because they were regarded as morally bad. Of course, there were adulterers, thieves and murderers, but when caught, were severely punished. Therefore, in the area of execution of punishment, the Ibadan authorities made use of slaves. Like the military, the judicial system in Ibadan was decentralised. Justice was organised on lineage system. The lineage court had initial jurisdiction over marriage, land, petty quarrels and all matters affecting the lineage members, followers and the slaves of the household. Though some of the large compound courts had jurisdiction over as many as a thousand people, a considerable part of the city's litigation occurred at the lineage court level [1]. The soldier-slaves were to enforce the commands of the private compound courts. And in fact, this practice continued well into the first decade of the twentieth century, despite its abolition by the British Colonial Administration. In fact, by 1914, when the practice still continued, the British Colonial Administration had to write a strong letter to warn the Bale to stop the act forthwith. The letter read in part:

...I want you to be very careful to stop your slaves (from) trying cases. I know it is the custom of the country, but it is a bad custom [10].

The soldier-slaves were not only to enforce the laws of the lower courts, they also carried out the orders of the supreme tribunal in Ibadan. They were always ready to despoil any convicts' houses whenever the tribunal ordered such people's property to be confiscated in consequence of a grave offence, such as arson, murder and so on. All movable items seized by a slave participating in this act of judicial spoliation belonged to 
him, while all the persons caught in the despoiled house were given to the town authorities who would only release them on the payment of a ransom. Such captives could be sold into slavery if the ransom was not paid on time. For instance, when Aiyejenku Foko, an important Ibadan Ologun, fell out with Are Latosa and some other chiefs, he was brought to book and his house was ordered to be plundered by the Omo-ogun many of whom were slaves [7].

By the 1870s, the soldier-slaves had wielded immense power and influence in Ibadan. The freehand given to them in the conduct of public affairs had become of such an alarming proportion that they started abusing the privileges they had. This abuse of power and influence brought about the downfall of many Ologun in our period. The slaves came up with the practice of ileke siso - tying of beads [1]. The soldier-slaves used this system to extort money from people by marking them out with beads tied on their wrists. Without any justification, the bead-branded people had to pay some money to have the wristlets of the beads removed. Although, the chiefs sometimes did not let such slaves go unpunished when they knew of their acts, the common people were often rather afraid to give offence to these powerful slaves. Therefore, a situation arose in which life for ordinary men and women, unless they bound themselves to powerful warrior-chiefs, was becoming less safe and secure [1].

It was to curb this irresponsible behaviour that Bale Orowusi (1870-1871) proposed that in their services to the community, the Ologun should rely more on the freeborn and less on the slaves. He also proposed that never should the slaves be entrusted with messages of importance to the interior, for having nothing to lose, their conduct would not be marked by moderation or discretion [4]. In fact, it can be argued that if Bale Orowusi's warnings were heeded, the sixteen years' war, probably, would have been averted. But the Ibadan Ologun did not and they continued to send their soldier-slaves with messages to the tributary towns. It was the bad manners in which these messengers and political residents conducted themselves, that smashed Ibadan's over-lordship of its tributary towns, leading to the war between 1877 and 1893.

The wars resulted in territorial expansion and eventually made Ibadan the metropolis of an expanding empire. By 1840, Oluyole, the Basorun of Ibadan until 1850, had put almost all the areas in the neighbourhood of Ibadan under his control. Among these were Ede, Osogbo, Iwo, Ikirun and Ilobu. In the 1850s, Ibikunle, the Balogun between 1851 and 1864, completed Oluyole's work by adding the vast region of the Ekiti and Ijesaland to Ibadan. However, it must be noted that not all the steps in the direction of Ibadan expansion was by force of arms. There were towns like Gbongan, Ароти, Ikire and a few others which voluntarily accepted Ibadan overlordship in exchange for protection. Ibadan thus had a large number of satellite towns and villages which supplied the town with agricultural products. The extensive farmlands of the Ologun and other chiefs, cultivated mainly by slaves, were located in some of the conquered areas [11].

\section{Slaves as Ibadan Ambassadors}

However, it was not enough for Ibadan to have acquired so much area of Yorubaland, it was necessary to consolidate her position in such areas by fashioning a system of government which would lead to permanent retention of her foothold. This became necessary because the nascent state of Ilorin had to be kept at bay and the absolute loyalty of the conquered territories ensured. But Ibadan could not provide enough resources to keep a standing army permanently in each of the conquered towns to ward off any attack from the Fulani of Ilorin and indeed, to ensure that the vassal states remained loyal. However, Ibadan's solution to these teething problems was the adoption of the 'Ajele system' as the Old Oyo had done in the administration of its satellite towns, before our period. The Ajele system was an 'indirect' system of government [12] used to govern the outlying territories, through the Ajele, the resident political representatives of Ibadan.

Having fashioned out this system of government, an effective political authority went into operation in such conquered territories from the 1850s, onwards. All the notable military chiefs had their own subject territories, where they exercised political control. An Ologun who had control over a subject town became known as Baba kekere (patron, lord or guardian) of the area [13]. A subject town might be given to an Ologun because of his special connection with it. For instance, Ogunmola was the Babakekere of Fesu, his home town, while Ayorinde had a greater number of Ekiti towns under his control because he was responsible for the conquest of many of them. In both cases, these chiefs should be persons of proven military ability and must have distinguished themselves as Ibadan warriors. It was possible for a notable chief to have more than one town under his control, but the Bale, being the ruler of Ibadan, often had the highest number of subject territories [14]. As patron of a town, the Ologun was responsible for keeping the town loyal to Ibadan and for ensuring peace and good governance within such a town. He also offered his subject towns adequate protection and military assistance when they were attacked. But to perform such functions, the Babakekere did not have to leave Ibadan. All he did was to post one of his political agents to the subject town as his representative. This political representative was the Ajele. The Ologun, who was the patron, was a sort of liaison officer between the colonies and the metropolis [15]. An Ajele was expected to be powerful, courageous and above all loyal. According to Awe, an Ajele's main qualification for his post: 
Was trust-worthiness and loyalty to Ibadan's cause; he did not need to be an Ibadan man, and indeed, it might be politically judicious that he should not be... The Ajele was usually an experienced warrior and trusted servant [15].

A careful thought over these qualities would clearly reveal that the majority of the Ajele appointed by the Ologun must have been from among the rank and file of their soldier-slaves, particularly the highly placed ones among them. For instance, an Ijesa and later an Ara-Ekiti man served as Ajele in Ado-Ekiti; and incidentally, it was the Ijesa and the Ekiti who predominated among the slaves in Ibadan.

The position of Ajele had such potentialities that an ambitious Ajele could constitute himself into the effective head of the town because his duties were such as to make him a man of great influence and authority. He had free access to everywhere in the town, he sat at the meetings of the council of chiefs and at their courts. However, he was not expected to interfere in strictly internal affairs which did not affect the fortunes of Ibadan [18]. In the places that voluntarily sought Ibadan's protection, the Ajele seldom exercised his authority, but they ensured that tributes and contingents of soldiers were sent to Ibadan. Thus, the relationship between the vassal territories and Ibadan was largely a kind of federation in which Ibadan had a definite predominance as primus inter pares' [15]. But in the conquered eastern provinces, the operation of the Ajele system by the Ibadan representatives was quite different. The Ajele was himself a ruler, he interfered in all domestic affairs that affected the fortunes of Ibadan. He was directly in charge of the territory's foreign policy and diplomacy. He had the power to reverse court decisions if they were not in line with the aspirations and objectives of his masters back home [11].

The Ajele represented his masters in all matters affecting conquered territories. In political and judicial affairs, matters that were beyond the settlement of the ruler and his chiefs were referred to him. In most cases, his judgment was final because disputed cases were rarely taken to the supreme judicial council. He also protected the citizens from the exactions or extortions of the personal representatives of the Babakekere, who visited the provinces mainly for exploitative purposes. On the issues affecting the foreign relations of the subject towns, the Ajele maintained constant contact with his master in Ibadan. He received all visitors to the territory in his compound and later introduced them to the town authorities. The visitors could only visit his territory with express approval of the metropolis $[15,11]$. As the representatives of the metropolis in the subject-towns and at the same time the conveyer of the views of the latter to the mother-state, the Ajele played dual ambassadorial roles in the course of discharging his duties.

It was also the responsibility of the Ajele to ensure that the economic obligations of the tributary towns to Ibadan were met. He collected articles such as horses and assorted foodstuffs which he forwarded to Ibadan at least in every six months. He also ensured prompt payment and collection of weekly tax. The collection of tolls at all the town gates was effectively organised by the Ajele with the temerity it deserved. Huts were built outside the town gate to receive custom dues from the caravans going in and out of the town. The tolls and levies from the provinces made substantial contribution to the finances of the metropolis. The Bale retained part of the revenues for public works and returned the rest to the chief as the guardian of the vassal town [15].

To protect its commercial advantages, Ibadan, with the help of the Ajele, established three frontier posts in Aiyede, Ikare and Otun, all in the eastern provinces. The frontier posts at Aiyede and Ikare were to prevent the Nupe from encroaching on Ibadan colonies. Otun, being a major market centre on the commercial high-way from Benin, through Ekiti to the Niger, was also very important. Therefore, to participate effectively in the Benin-Ekiti-Niger trade and check Ilorin, the frontier posts of Ibadan at Otun were manned by strong and loyal soldiers, who were mostly slaves [17, 11]. Most importantly, the Ajele also ensured that contingents of soldierslaves and other domestic slaves were sent to Ibadan as the need arose. These were obviously to swell the metropolitan armies and provide the required labour for other economic activities. It was also the responsibility of the Ajele to raise an army to constantly ward off any attack before sending for reinforcements in Ibadan.

This imperial system of government, before the 1870 s was so effectively implemented that, impressed Captain Glover (later Governor of Lagos), in 1859, lauded its success in each of the subject towns of Ibadan and recommended that the British Consul at Lagos should learn from it [1]. However, by 1870s, the Ajele system had become rather irksome to Ibadan's subject-towns. The imperial structure was becoming less effective. The Ajele no longer exercised the tact befitting his office and in most cases alienated local rulers by his high handedness. Too often, unpopular rulers were imposed on unwilling citizens and tributary towns were humiliated in other ways. Ibadan regarded the vassal towns, particularly the Ekiti and Ijesa towns, primarily as a source of wealth, cheap slaves to work their farms, swell the private armies of the Ologun; and generally as a rich field for exploitation [16]. The real cause of these was not so much the fault of the Ajele, but mainly of those other Ekiti and Ijesa slaves who an Ologun often sent as his emissaries.

These messengers, once they were outside the gates of Ibadan, would secure the services of drummers to sing the praises of their masters as if the latter were coming. On entering a town, the Ajele would introduce them as the messengers of the Ologun to the town authorities so that they could be provided with comfortable accommodation. They were fed by their hosts with such expensive diet that the latter could ill afford. The result 
was that many people including the old were levied to meet the expenses. But despite the expensive treatment these unwanted visitors received, cruelty and debauchery were their reciprocity. The women and girls of their hosts were cohabited with by force and at the end of their visits, they generally returned to Ibadan with assorted valuables including slaves [4]. But the irony is that messengers who were perpetrating all the mischief were mainly the Ijesa and Ekiti slaves of Ibadan, who had been sent with messages to their own native towns. This situation got to a head that the mention of Ibadan stank in the nostrils of all the Ijesa and Ekiti, thus, they waited patiently for an opportuned time to smash the yoke of Ibadan. In fact, the belated action of some young chiefs in Ibadan to check these overzealous messengers, by executing about three [4] of them had only slight and transient effect, as the feelings in the provinces were by no means allayed. The circuit was indeed, complete and the expected spark was only a question of time. Therefore, by 1878, when the Ekiti parapo war that smashed the imperial political machine of Ibadan in her colonies began, it was clear that the crimes perpetrated by the slaves provided the occasion.

\section{Conclusion}

The Ibadan of our period was a good example of an organised state. Though the leaders and other freeborn individuals demonstrated good knowledge of statecraft in the administration of the 'empire', in state enterprise, the slaves were the vocal point in the execution of various government policies as we have discussed. The slaves were drafted into political arrangement and they discharged the enormous responsibilities placed on them by their masters with operational efficiency, though sometimes with some level of overzealousness. As gate-keepers, they were not only to collect tolls for the overall development of the military state of Ibadan; they were also expected to ward-off any external invasion and other undesirable elements who may try to enter Ibadan territory to foment trouble. Security of lives and property were also taken seriously by the military leaders that slaves were equally drafted constantly to escort traders and visitors to safety. In the area of dispensation of justice, slaves played very important role in enforcing the laws of both the lower courts and the supreme tribunal in Ibadan. In foreign relations, slaves were used as Ibadan ambassadors, particularly in the northern and eastern Yorubaland where Ibadan had absolute political control. Slaves were sent to such areas as permanent representatives of Ibadan and they were to keep such areas absolutely loyal to Ibadan, ensure peace and good governance. They must as a rule report back to the centre all activities in the satellite territories. These ambassadors, who were mostly slaves, were christened Ajele. The Ajele however, sometimes in the discharged of their duties became overzealous by abusing the privileges, power and influence which they were enthroned with. Despite some of the shortcomings of the Ibadan experiment in the involvement of slaves in the conduct of public affairs, Captain Glover in 1859, lauded the success of the system in each of the subject towns of Ibadan, and recommended that the British Consul in Lagos should learn from it.

\section{Endnotes}

[1] Oroge, E. A. (1971), The Institution of Slavery in Yorubaland with particular reference to the nineteenth century Unpublished Doctoral Dissertation, University of Birmingham, 1971, 102

[2] Ogundipe, I. B Chief (55+), Balogun of Ibadan. Interviewed at his residence, E3/53, Malo Street, Oranyan, Ibadan.

[3] Fadipe, N. A. (1970), The Sociology of the Yorubas, Ibadan, 1970

[4] Johnson, S., (1960), The History of the Yorubas; From the Earliest to the beginning of the British Protectorate,(pp. 91-92). Lagos, CSS Limited.

[5] Ajisafe, A. K. (1924) A History of Abeokuta, London; Bingway, 1924), 46

[6] Callaway, A. (1967) 'From Traditional Crafts to Modern Industries' in P. C. Lloyd et al. (eds.) The City of Ibadan (p. 153) Cambridge: London, 1967)

[7] Akinyele's Outline History of Ibadan, Vol. I, translated, revised and enlarged by Kemi (Ibadan: Morgan, Ibadan, n.d)

[8] Hinderer, D. Journal of the Quarter ending, September 25, 1853, CMS. CA2/049 (b)

[9] Falola, T. The Political Economy of an African State: Ibadan, 1830-1900, (Ife: 1984), 69 - 70

[10] Grier to Bale, April, 10, 1914, Ibadan Historical Paper, Mapo.

[11] Falola, T. 'Power Relations and Interactions Among Ibadan Slaves', African Economic History, 1986

[12] Atanda, . A. J. The New Oyo Empire, (London: Longman, 1973), see especially $45-84$

[13] Mosaderin O. A. Chief (60+), Ikolaba Olubadan. Interviewed at his residence in Oranyan, Ibadan.

[14] Elgee, C. H. The Evolution of Ibadan, (Lagos, 1914), 31 - 37

[15] Awe, B. A. 'The Ajele System: A Study of Ibadan Imperialism in the nineteenth century', J.H.S.N., 3, 1, 1964

[16] Awe, B. A. 'The Rise of Ibadan as a Yoruba Power in the nineteenth Century' D. Phil, Oxford, 1964, 146

[17] Akintoye, S. A. 'The Economic Foundations of Ibadan's Power in the nineteenth Century' in I. A. Akinjogbin and S. O. Osoba (Eds.) Topics on Nigeria Economic and Social History, (Ife, 1980)

[18] Awe, B. A. 'The end of an experiment: The collapse of the Ibadan Empire, 1877-1893', J. H.S. N., 3, 2, Dec., 1965 